\title{
¿Cuál es su diagnóstico?
}

\author{
What should the diagnosis be?
}

Paciente mujer de 39 años de edad con antecedentes personales de Miotonía congénita (Enf. de Thomsen), Hipotiroidismo primario subclínico y bocio difuso y Alergia a Penicilinas. Acude a consulta de Cirugía Oral y Maxilofacial, presentando tumoración de partes blandas en hemicara izquierda en relación con pared anterior de seno maxilar desde hace un mes.

A la exploración física se objetiva tumoración localizada a nivel de la región geniana izquierda de $1,5-2 \mathrm{~cm}$ de diámetro, bien delimitada, móvil, de consistencia elástica y no adherida a piel ni planos profundos. No se observa nada más patológico en el resto de la

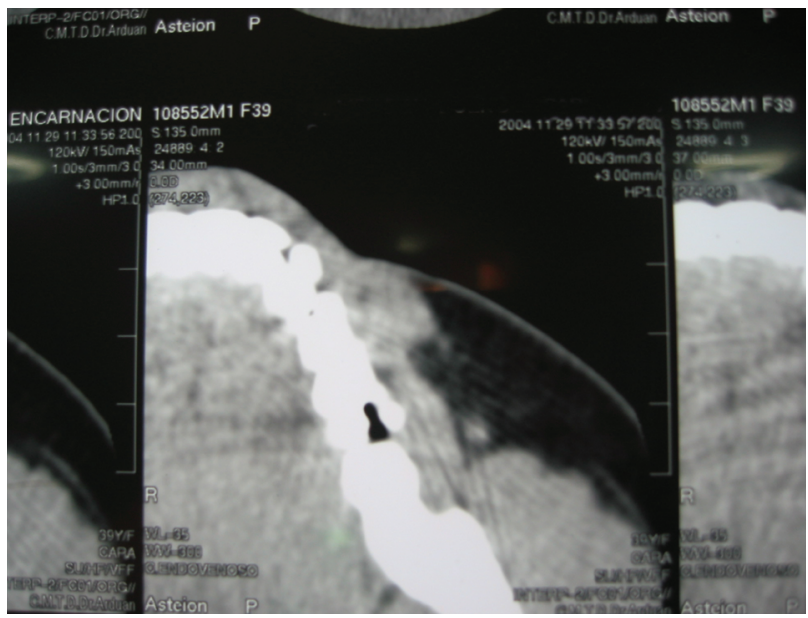

Figura 1. Engrosamiento de partes blandas de morfología nodular, localizado a nivel de pared anterior de seno maxilar izquierdo. Figure 1. Thickening of soft tissue with a nodular morphology, by the anterior wall of the left maxillary sinus. exploración.

Ante estos hallazgos solicitamos una Punción-Aspiración con aguja fina (PAAF), no obteniendo material suficiente para llegar a un diagnóstico. Al mismo tiempo se solicita una Tomografía Computarizada facial (TC) (Fig. 1), en la cual se visualiza, en las partes blandas situadas anteriormente con respecto a la pared anterior del seno maxilar izquierdo, un engrosamiento que adopta una morfología nodular, que capta moderadamente contraste y que presenta una extensión craneo-caudal aproximada de 1,8 cm. Esta lesión se acompaña de hiperintensidad de la grasa subyacente, aunque no produce erosión ni deformidad ósea.

Por último se realiza estudio preoperatorio y se programa la extirpación quirúrgica. remainder of the examination.

Female patient, 39 years old, with a medical history of congenital myotonia (Thomsen's disease), subclinical primary hypothyroidism with diffuse goiter and allergy to penicillins. She attended the Oral and Maxillofacial Unit as over the previous month she had noted a tumorlike mass of soft tissue on the left side of her face by the anterior wall of the maxillary sinus.

On physical examination a tumorlike mass was observed that was located by the left genian area. It had a diameter of $1.5 \mathrm{~cm}-2 \mathrm{~cm}$, was well-defined, movable with an elastic consistency and it did not adhere to the skin nor to the deeper layers. No further pathological findings were made during the

Given these findings, a Fine Needle Aspiration Puncture (FNAP) was requested, but not enough material was obtained to give a diagnosis. A facial Computed Tomography (CT scan) was also requested (Fig. 1) that showed a thickening of the soft tissue in front of the anterior wall of the left maxillary sinus. It had a nodular morphology that showed moderate enhancement and that revealed a craniocaudal extension of approximately $1.8 \mathrm{~cm}$. The underlying fat of the lesion was also hyperintense although there was no bone erosion or deformity.

Lastly a preoperative study was carried out and the surgical excision was programmed. 


\section{Adenoma pleomorfo intraoral}

\section{Intraoral Pleomorphic Adenoma}

\section{S. Gallana Alvarez¹, F. Mayorga Jimenez², J. Herce López³, M. Díaz Delgado4}

Bajo anestesia local, se llevó a cabo la extirpación de una masa firme y bien encapsulada, a través de una incisión en fondo de vestíbulo izquierdo del paciente (Fig. 2).

La mucosa que cubría la lesión era de características normales. La pieza quirúrgica obtenida presentaba un diámetro de $1 \times 1,8 \mathrm{~cm}$, era de consistencia elástica y no presentaba calcificaciones. (Fig. 3).

El estudio anatomopatológico definitivo de la pieza extirpada, reveló un adenoma pleomorfo ó tumor mixto de glándula salivar menor (Fig. 4).

\section{Discusión}

Los tumores de glándulas salivales representan aproximadamente el $3 \%$ de las neoplasias de cabeza y cuello en el adulto y alrededor del $8 \%$ de los mismos en la infancia. ${ }^{1}$

Entre ellos el adenoma pleomorfo, es el tumor de glándula salivar más frecuente, representando entre el 40 y el $70 \%$ de todos los tumores que afectan a glándulas salivales mayores y menores.2,3

Este tumor puede aparecer a cualquier edad, aunque es más prevalente entre la $4^{\mathrm{a}}$ y la $6^{\mathrm{a}}$ década de la vida, y es ligeramente más frecuente en mujeres. ${ }^{4}$

Los tumores que se desarrollan en las glándulas salivares menores, representan el $22 \%$ de todas las neoplasias de glándulas salivares. La mayoría de ellos son malignos, siendo benignos sólo el 18\%, y dentro de estos el adenoma pleomorfo es el tumor benigno más frecuente. ${ }^{5}$ El lugar más frecuente dónde aparece cuando afecta a

\footnotetext{
1 Médico Interno Residente. Servicio de Cirugía Oral y Maxilofacial.

2 Médico Adjunto. Servicio de Cirugía Oral y Maxilofacial.

3 Médico Interno Residente. Servicio de Cirugía Oral y Maxilofacial.

4 Médico Interno Residente. Servicio de Anatomía Patológica.

Hospital Universitario Virgen Macarena. Sevilla, España
}

\section{Correspondencia:}

Silvia Gallana Alvarez

C/ Isbilia No 10

41907 Valencina de la Concepción (Sevilla), España

E-Mail: sgallana@hotmail.com
Under local anesthesia, a firm, well-encapsulated mass was removed by means of an incision at the back of the patient's left vestibule (Fig. 2).

The characteristics of the mucosa covering the lesion were normal. The surgical specimen that was obtained had a diameter of $1 \times 1.8 \mathrm{~cm}$. Its consistency was elastic and it did not have any calcifications (Fig. 3).

The definitive anatomopathologic study of the sample removed revealed a pleomorphic adenoma or mixed tumor of the minor salivary glands (Fig. 4).

\section{Discussion}

Tumors of the salivary glands represent approximately $3 \%$ of the neoplasms of the head and neck in adults and around $8 \%$ in infants. ${ }^{1}$ Of these, the pleomorphic adenoma is the most common tumor of the salivary glands representing between 40 and $70 \%$ of all the tumors affecting the major and minor salivary glands. ${ }^{2,3}$

This tumor can appear at any age, although it is more prevalent between the $4^{\text {th }}$ and $6^{\text {th }}$ decades in life and it is slightly more frequent in women. ${ }^{4}$

The tumors that develop in the minor salivary glands represent $22 \%$ of all neoplasm of the salivary glands. Most of these are malignant and only $18 \%$ are benign. Within these the pleomorphic adenoma is the most common benign tumor. ${ }^{5}$ The most common place for it to appear when affecting the minor salivary glands is the palate (up to $50 \%$ of cases), ${ }^{5}$ followed by the upper lip, buccal mucosa, floor of the mouth, tongue, pharynx, retromolar area and nasal cavity.

Recently authors such as Jansisyamont and cols., ${ }^{6}$ registered a series of 80 cases of minor salivary gland tumors, with a rate of $21.3 \%$ for pleomorphic adenomas with $39.5 \%$ affecting the palate.

Of the malignant tumors affecting the minor salivary glands, the most common was the cystic adenoid carcinoma. ${ }^{7}$ 
glándulas salivares menores es el paladar, (hasta el 50\% de los casos) ${ }^{5}$, seguido por el labio superior, mucosa bucal, suelo de boca, lengua, faringe, área retromolar y cavidad nasal.

Recientemente autores como Jansisyamont y cols., ${ }^{6}$ han registrado en une serie de 80 casos de tumores de glándula salivar menor, una frecuencia de $21,3 \%$ de adenomas pleomorfos, afectando en un $39,5 \%$ de los casos al paladar.

Dentro de los tumores malignos que afectan a glándulas salivares menores, el más frecuente es el carcinoma adenoide quístico. ${ }^{7}$

Clínicamente el adenoma pleomorfo aparece cómo un nódulo habitualmente único, de crecimiento lento e indoloro. La piel o la mucosa que lo rodea suele tener características normales, y el tumor no se adhiere a planos profundos, excepto cuando afecta al paladar duro; en estos casos puede extenderse hacia el periostio y el hueso subyacente. ${ }^{4}$

A la palpación pueden tener cavidades quísticas, siendo en estos casos blandos, mientras que si presentan formación ósea o cartilaginosa su consistencia es más dura.

En cuanto a la histología, el adenoma pleomorfo es una mezcla de elementos epiteliales y estromales, el estroma puede ser condroide, mixoide o hialino. La histogénesis del tumor se relaciona con una proliferación de células de características ductales y/o mioepiteliales. La diferenciación mioepitelial de las células supone un papel importante a la hora de determinar la apariencia final de los tumores mixtos. La mayoría de los estudios muestran una gran variedad de células en los tumores mixtos, en unos casos con características epiteliales y en otros son completamente mioepiteliales, y entre estos dos extremos pueden aparecer células menos diferenciadas que muestran elementos ductales y mioepiteliales al mismo tiempo. ${ }^{8}$

Para llegar al diagnóstico de estos tumores, es importante la presentación clínica de los mismos, ya que puede orientarnos hacia su posible naturaleza benigna ó maligna. Son fundamentales tanto la PAAF cómo la biopsia incisional, y en este sentido existen estudios cómo el desarrollado por CeruIli y cols., 7 que comparan la eficacia de ambas técnicas para establecer el diagnós-

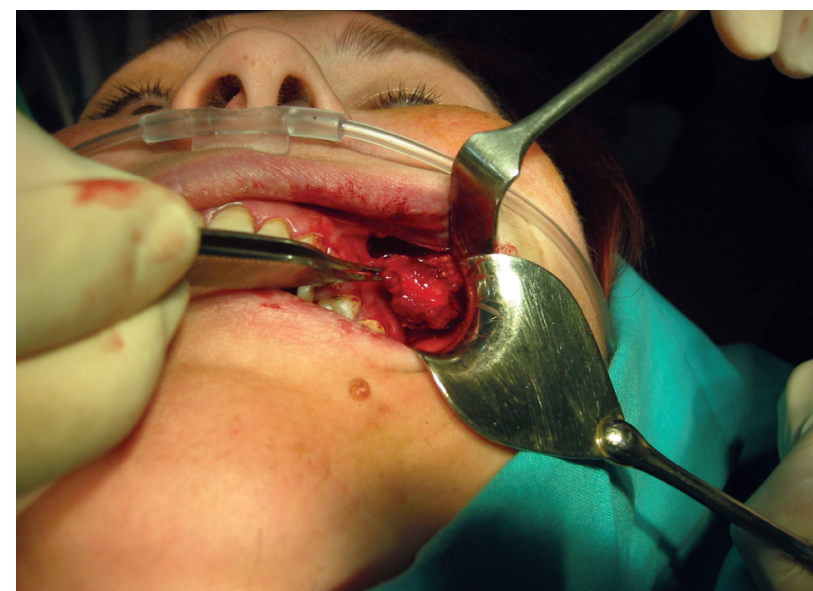

Figura 2. Se aprecia abordaje quirúrgico en fondo de vestíbulo izquierdo.

Figure 2. The surgical approach can be appreciated at the back of the left vestibule.

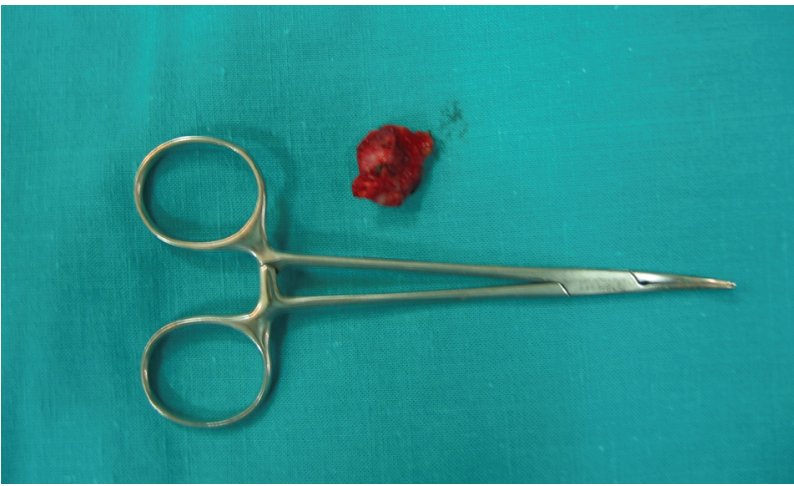

Figura 3. Pieza quirúrgica de $1 \times 1^{\prime} 8 \mathrm{~cm}$, de consistencia elástica. Figure 3. Surgical specimen measuring $1 \times 1.8 \mathrm{~cm}$, with an elastic consistency.

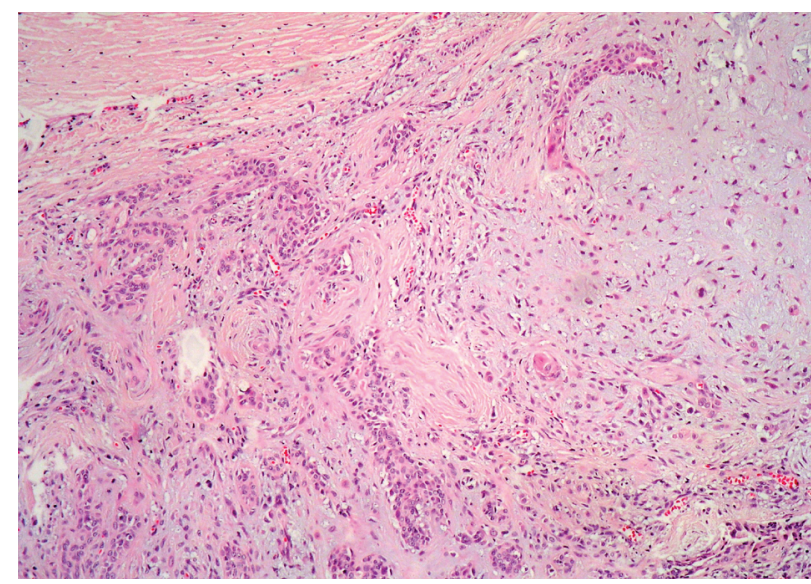

Figura 4. Imagen microscópica de la preparación histológica, dónde se observan túbulos alineados por hilera ductal, y otra hilera periférica de células mioepiteliales modificadas dentro de una matriz condroide/mixoide.

Figure 4. Microscopic image of the histologic preparation showing rows of tubular cells lined by ductal structures, and another perip heral string of modified myoepithelial cells within a chondroid/myxoid matrix.
Clinically the pleomorphic adenoma appears as a painless, slow-growing nodule that is usually solitary. The skin or mucosa that surrounds it tends to have normal characteristics and the tumor does not adhere to deeper areas, except when it affects the hard palate. In these cases it can extend towards the periosteum and the underlying bone. ${ }^{4}$

On palpation it may have cystic cavities, these being soft, but if bone or cartilaginous formation is present it will be firmer.

With regard to its histological characteristics the pleomorphic adenoma has a mixture of epithelial and stromal elements. The stroma can be chondroid, myxoid or hyaline. The histogenesis of the tumor is related to a proliferation of cells with ductal and/or myoepithelial characteristics. Myoepithelial cell differentiation has an important role when determining the final appearance of mixed tumors. Most studies show a large variety of cells in mixed tumors, in some cases with epithelial characteristics and in others they are completely myoepithelial, and, between these two extremes, less differentiated cells may appear that have both ductal and myoepithelial elements. ${ }^{8}$ In order to diagnose these tumors, their clinical presentation is important, as this can help us determine their possible benign or malignant character. FNA is fundamental as is an incisional biopsy, and in this sense there are studies such 
tico preoperatorio en casos de tumores de paladar; llegando a la conclusión de que la PAAF presenta una precisión del 91,6\% en el diagnóstico del adenoma pleomorfo vs carcinoma adenoide quístico cuando se desarrollan en glándulas salivares menores en paladar.

Por último el TAC es útil para establecer la localización exacta del tumor y permite orientar el tratamiento quirúrgico.

El potencial de transformación maligna del adenoma pleomorfo se estima en torno al $6 \%$, aunque este riesgo aumenta hasta el $10 \%$ cuando el tumor tiene más de 15 años de evolución. ${ }^{1}$

El diagnóstico diferencial de los adenomas pleomorfos intraorales, cuando afectan a la mucosa bucal, hay que establecerlo fundamentalmente con neurofibromas y otros tumores mesenquimales benignos.

El tratamiento de estos tumores es esencialmente quirúrgico; en aquellos tumores benignos aparentemente bien encapsulados, la resección tumoral con un margen adecuado de tejido sano circundante es necesaria para prevenir posibles recurrencias locales, ${ }^{9}$ ya que estos tumores se caracterizan por poseer extensiones microscópicas hacia el tejido sano circundante debido a dehiscencias en la falsa cápsula que los rodea.

Spiro y cols., ${ }^{10}$ registraron una tasa de recurrencias del $7 \%$ de 1342 pacientes con neoplasias parotídeas benignas y un $6 \%$ en pacientes con tumores benignos de glándula salivar menor.

Otra opción terapeútica sería la radioterapia postoperatoria que permitiría reducir la tasa de recurrencias sobre todo en aquellos casos en los que el tumor afecta al espacio parafaríngeo, y no es posible la resección completa. ${ }^{11}$

\section{Bibliografía}

1. Unlu H, Celik O, Demir M, y cols. Pleomorphic adenoma originated from the inferior nasal turbinate. Auris Nasus Larynx 2003;30:417-20.

2. Lopes MA, Kowalski LP, et al. A clinicopathologic study of 196 intraoral minor salivary gland tumours. J Oral Pathol Med 1999;28:264-7.

3. Lopez-Cedrún JL, González-Landa G, Birichinaga B. Pleomorphic adenoma of the palate in children: report of a case. Int J Oral Maxillofac Surg 1996;25:206-7.

4. Clauser L, Mandrioli S, Dallera V. Pleomorphic adenoma of the palate. / Craniofac Surg 2004;15:1026-9.

5. Beckhardt RN, Weber RS, Zane R, y cols. Minor salivary gland tumors of the palate: Clinical and pathologic correlates of outcome. Laryngoscope 1995;105:1155-60.

6. Jansisyanout $\mathrm{P}$, Blanchaert $\mathrm{H}, \mathrm{y}$ cols. Intraoral minor salivary gland neoplasm: a single institution experience of 80 cases. Int J Oral Maxillofac Surg 2002;31:257-61.

7. Cerulli G, Giancarlo R, Perugini M, el al. Differential diagnosis between adenoid cystic carcinoma and pleomorphic adenoma of the minor salivary glands of palate. J Craniomaxillofac Surg 2004;15:1056-60.

8. Regezi JA, Sciubba J, Jordan R. Salivary gland disseases. Oral Pathology Clinical Pathologic correlations (ed 4), Philadelphia, Saunders; 2003:196-8.

9. To E, Tsang W, Tse G. Pleomorphic adenoma of the lower lip: Report of a case. J Oral Maxillofac Surg 2002;60:684-6.

10. Spiro RH. Salivary neoplasm: overview of a 35 years experience with 2807 patients. Head Neck Surgery 1986;8:177-184.

11. Bent JP, Dinges D. Pathologic quiz case- Minor salivary gland Pleomorphic adenoma of the parapharingeal space. Arch Otolaryngol Head Neck Surg 1992;118: 664-6. as those carried out by Cerulli y cols., ${ }^{7}$ that compare the efficiency of both techniques for establishing a preoperative diagnosis in palatal tumor cases. They reached the conclusion that FNA had a precision of $91.6 \%$ in the diagnosis of pleomorphic adenoma vs. cystic adenoid carcinoma when appearing in the minor salivary glands of the palate.

Lastly CAT scans are useful for establishing the exact location of the tumor and it enables adapting surgical treatment.

The potential for malignant transformation of the pleomorphic adenoma is estimated at around 6\%, although this risk increases to $10 \%$ when the tumor has been evolving for more than 15 years. ${ }^{1}$

The differential diagnosis of intraoral pleomorphic adenoma, when the buccal mucosa is affected, has to be established fundamentally with neurofibromas and other benign mesenchymal tumors.

The treatment for these tumors is essentially surgical. For benign tumors that are apparently well-encapsulated, tumor resection with an adequate margin of surrounding healthy tissue is necessary for preventing possible local recurrence9, as these tumors have characteristic microscopic extensions towards surrounding healthy tissue due to dehiscence of the false capsule surrounding it.

Spiro and cols. 10 registered a rate of recurrence of $7 \%$ in 1342 patients with benign parotid neoplasms and 6\% in patients with benign tumors of minor salivary glands.

Another therapeutic option would be postoperative radiotherapy that would permit reducing the rate of recurrence especially in those cases where the tumor affects the parapharyngeal space and complete resection is not possible. ${ }^{11}$ 